\title{
Succession Planning and the Maintenance of High Performance Standards by Fast-Food Companies in Nigeria
}

\author{
Baba, A. Samuel \\ University of Port Harcourt, Nigeria \\ babasam97@yahoo.com
}

\author{
Edwinah, Amah (Ph.D.) \\ University of Port Harcourt, Nigeria \\ edwinah4christ@yahoo.com
}

\begin{abstract}
This study is necessitated by the growing emphasis in today's business environment for performance measurement and standards; given changes in relative and associated constructs and settings such as leadership, the socio-economic as well as the socio-political context; hence this study evaluates the effect of succession planning on the maintenance of performance standards by fast-food companies in Nigeria. A total of 62 employees from 21 fast-food outlets in Port Harcourt comprised the sample size for the study; with data generated through the use of structured questionnaire copies. Two hypothetical null statements of no association between the dimensions of succession planning (mentoring and management development) and the maintenance of performance standards were tested and found to be false given the significance of the correlations. Therefore we assert that the careful and predetermined succession of leadership is imperative to the maintenance of performance standards and recommend that adequate policies and frameworks be instituted to support and guide such events.
\end{abstract}

Keywords: succession planning, leadership, performance standards, mentoring, management development.

\section{INTRODUCTION}

All over the world, there is growing evidence that Small and Medium-scale Enterprises (SMEs) play an important role in the national economic development of any country. They are becoming more and more a subject of high attention in the developing countries, countries in transition but also in the countries with developed economies. SMEs are the engine of economic development, contributing to sustainable growth and employment generation in a significant manner. However, most times we observe that these flourishing enterprises that have made remarkable impact in their respective industries wind-up just few years after the death of their founders or perhaps some of them as a result of the exit of one or two key players in the organization. These persons leave the organization either voluntarily (retirement or pursuit of new aspiration) or involuntarily (relieved of appointment or death). Organizations as a result of this are faced with vacancies in leadership or inadequacy or lack of competent and capable successors to fill the vacancies (Collins, 2009; Hazarika, 2009).

In order to bridge this gap and ensure organizational survival/continuity through the maintenance of performance standards, which is the ultimate goal of every establishment, succession planning, which is that approach that ensures that necessary talent and skills will be available when needed, and essential knowledge and abilities are maintained when employees in critical position leave, is very necessary; no wonder, Charan, Drotter, and Noel (2001) suggest that it is essential for organizations to train successors before the vacancies are created, buttressing the same point, Hazarika (2009) stipulates that for organizations to survive, that there is need to plan for succession of older (outgoing) employees. Succession planning in the words of Charan et al, (2001) is perpetuating the enterprise by filling the pipeline with high-performing people to assure that every leadership level has an abundance of these performers to draw from, both now and in the future. From this perspective, succession planning is seen as management pipeline that accelerates management performance over a period of time.

Several research (Garman \& Glawe, 2004; Charan et al, 2001; Hazarika, 2009) have been conducted over the decade as it relates to succession planning especially in family-owned businesses. Despite these numbers of studies, little empirical studies exist on succession planning and the maintenance of high performance standards in developing countries especially in Nigeria. To bridge this gap, this study seeks to investigate whether succession planning has a relationship with the maintenance of 
high performance standards of SMEs in Nigeria, by concentrating on the fast food industry in Port Harcourt city of Rivers state.

\subsection{Research Questions}

1. What is the relationship between mentoring and the maintenance of high performance standards?

2. What is the relationship between management development and the maintenance of high performance standards?

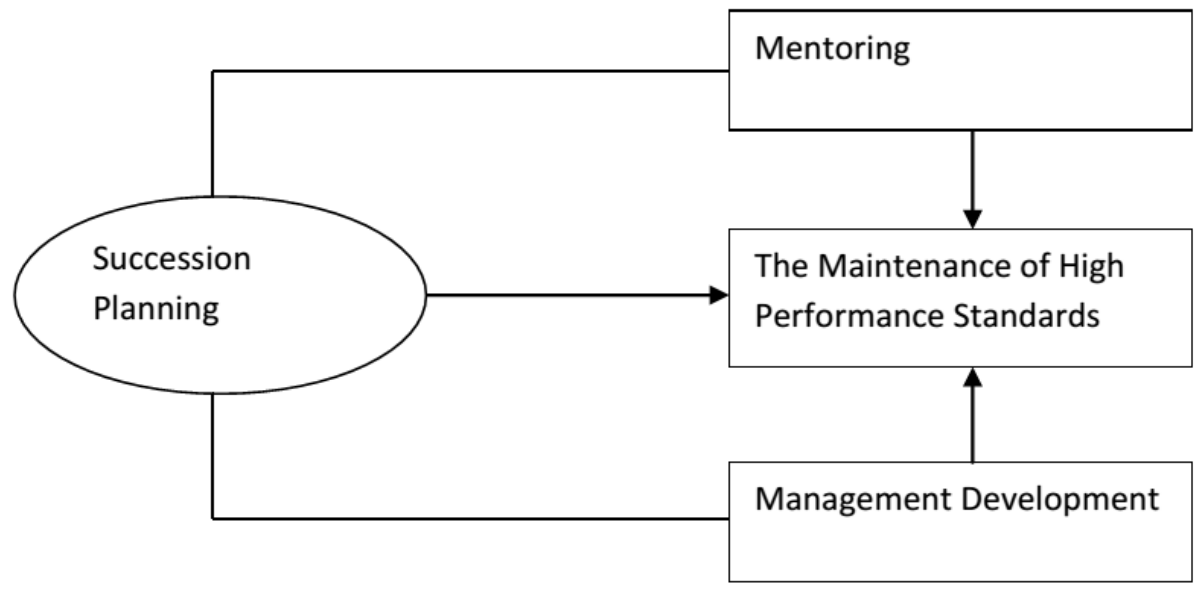

Fig1. Operational Framework of the Study

\section{REVIEW OF RELATED LITERATURE}

\subsection{Succession Planning}

Collins (2009) defines succession planning as a process that can provide seamless leadership transition across the organization. It is an organized process comprising the identification and preparation of potential successor to assume new role (Garman \& Glawe, 2004). In defining succession planning Hackett (1997) asserts that it is concerned with identifying the key jobs in one organization and ensuring that if anything, planned or unplanned were to remove the present job holder from his post, there would be someone ready to take the lost position. Wendy Hirsh (2000) sees succession planning as a process by which one or more successors are identified for key posts (or group of similar key posts), and career move and/or development activities are planned for these successors.

Filley et al (1976) regards succession management as a coordination of plans, controls, organizing and directing of an organization's staffing function to ensure uninterrupted continuity in objectives during change of personnel. It is aimed at ensuring that a sufficient supply of appropriately qualified and capable men and women are available to meet the future needs of the organization (Mullins, 1996). Severally, the terms "Succession Planning" "replacement planning" "executive manpower planning" and "career planning" are used interchangeably to mean the same thing though some slight distinctions do exist. Cannor and Carson (1982) maintained that succession planning is more than merely climbing the ladder. It involves broader development and wider look at the organization. In distinguishing between replacement planning and succession planning, Kathryn and Martins (1994) stated that "while replacement planning focuses on specific candidates who could fill designated managerial positions, succession planning is a means of identifying individuals with high potential and ensuring that they receive appropriate training and job assignments aimed at their long run growth and development. This distinction however, lies on the technical interpretations. Succession planning is different from career planning in the sense that career planning is an aspect of human resource planning that is complementary to succession planning. While career planning is concerned with the individual development, succession planning is concerned with the overall organizational development; This is as Caudran (1996) contends that at times of unexpected death or resignation of executives, succession management serves as crucial part of human resource strategy assuring suitable leaders are ready for appointment, hence, Charan et al (2001) suggest that it is essential for organizations to train successors before the vacancies are created. Hazarika (2009) lending credence to the point opines that it is essential if organizations must survive, that they plan for succession of older (outgoing) employees. 


\subsubsection{Dimensions of Succession Planning}

The dimensions of succession planning as adopted in this study include Mentoring and Management Development.

Mentoring: William, James and Susan (2002) define the mentor as a corporate manager who supervises, coaches, and guides selected lower - level employees by introducing them to the right people and generally being their organizational sponsor. In reality, an informal type of mentoring goes on in most organizations on regular basis as older employees assist younger workers. Networking and having mentors is essential for succession planning because it builds and develops managers by widening their knowledge and better understanding of the overall operations and to prepare for task ahead. Agulanna and Awujo(2005) define mentoring as the process of using specially selected and trained people to provide guidance and advice which will help to develop the careers to the people allocated to them. Mentoring is used to complement learning on the job which of course is the best way of obtaining particular knowledge and skills. Pitney and Ehler (2004) assert that mentoring is widely accepted as a strategy for facilitating the professional growth and development of students while they are socialized into a discipline. As a component of the professional socialization process, mentoring can influence how individuals prepare themselves and develop various values skills, knowledge and attitudes throughout their academic and professional careers. Delegation also is part of mentoring but this time around, it is a one on one between the mentor and the mentee. The mentor assigns duties to the mentee who carries them out.

Management Development: According to Mullins (1999), management is the cornerstone of organizational effectiveness and the contribution to social needs of the society. This applies to public sector and service organizations as to many other industries. Managers need a balance of technical, social and conceptual knowledge and skills, acquired through a blend of education and experience. There is therefore a continual need for managerial development of both present and future managers. Development is concerned with preparing the manager for expected changes in the job, or for anticipated future job or role. However, management development is meant to include an element of training. For Mullins, a more general interpretation views management development as an integral part of the process of organizational development.

Management development is described as the process from which managers learn and improve their skills not only to benefits themselves but also their employing organizations (Hazarika, 2009; Susan, 2002). Managers are exposed to learning opportunity whilst doing their jobs, if this informal learning is used as a formal learning process then it is regarded as management development. William, James and Susan (2002) define management development as the process of training and educating employees to become good managers and their monitoring the progress of their managerial skills over time. According to Amah (2010), The aim of management development is to make sure that the men set aside as future executive are properly trained, and ready for action, by the time they are due to take their appointed place in the overall plan. Amah contend that in selecting for top management, director level, whether from inside or by external talent spotting, it may be considered advisable to use sophisticated tests designed to demonstrate managerial ability and general group effectiveness. She recommends a group approach which extends to such organized procedure as so- called "Psychological week - end' or 'country house' conditions, where candidates take part in publicspeaking sessions, group discussion, debates, exercise, etc., and are closely studied by specialist on all points of view. This includes an assessment of their social ability to mix well, to take part in intelligent conversation, and to conduct themselves correctly at table.

\subsection{Maintaining High Performance Standards}

A performance standard is a management-approved expression of the performance requirements or expectation that must be met to be appraised at a particular level of performance (Sims 2007). A fully successful standard must be established for each critical element and must be included in the employee performance plan. High-performing businesses have developed principles and strategies for achieving customer satisfaction. Improving service quality to meet customers' standards is an ongoing part of doing business, in this way customers drive the market and the organization. The key 
to sustained survival and organizational success lies not only in the rational, quantitative approaches, but more to employee's involvement and motivation to work (Sims 2007). By establishing highly motivating environment, leaders inspire employees to expend high levels of performance (Dubinsky and skinner 2004: Isaac et al 2001: O'Reily and Pfeffer 2000: Skinner 2001). Black and Lynch (2004) found that firms that reengineered their workplaces to incorporate high performance practices experienced higher productivity and survival. Similarly, Lawler et al (1992 found out that companies that use 'high performance' work practices reported significantly higher financial success. Huselid (1995) found out that high performance work practices influenced the firm performance; this is as factors such as performance management and performance measurement have been revealed to be imperative for sustained performance standards.

Performance Management: Having an efficient performance management process and tools is essential for employee motivation for high performance. This requires management to have variety of skills which ensures that employees complete assigned task within the required time. (Milligan et al, 1996). The most vital issue with any performance management system is how seriously it is taken and how devotedly it is used by managers and employees. (Pulakos, 2009). Performance management must be viewed within an enterprise as a tool to improve on employee motivation for high performance. (Cokins, 2009) The effective management of performance requires a solid understanding of the performance domain. This is the foundation for assessing and improving performance within a company.

Performance Measurement: Performance measurement could be defined as the regular measurement of the results (outcomes) and efficiency of services or programs (Andersen \& Fagerhaug, 2002). When performance is not measured or is measured inaccurately, those using the information will be misled and bad judgments will be likely followed. Therefore, the old saying "garbage in garbage out" pro-vides more credence. (Hatry 2006) maintains that Performance measurement offers general information that can be exploited for decision making purposes both for management and for all levels of employees. In this aptitude, the performance measurement system can become the instrument panel. This instrument panel is used for strategic maneuvering, day to day running of the organization and planning, implementing improvements and changes (Andersen \& Fagerhaug, 2002).

\subsection{Relationship between Mentoring and Maintaining High Performance Standards}

Agulanna and Awujo (2005) asserts that human beings are the agents who accumulate wealth, exploit material resources, build social, economic, and political organizations and achieve national development. When they are trained (Mentored), they become more effective and efficient in the above exercises. It is therefore pertinent at this point to bring in the Paul Principle which states "overtime, people become uneducated and therefore incompetent to perform". The implication of the principle is that training and retraining (mentoring) is imperative. Mentoring is needed when organization's goals can be advanced by improved employee-performance. High performance standards are required to keep the organization going and that is a way of sustaining its continuity.

Mentoring is a developmental relationship that fosters individual abilities and knowledge and increases the understanding of immediate and long-term needs of the organization (Amah and Jaja, 2013). The aim is to ensure learning at all levels and to readily provide the HR needs. Gray, (1986) cited in Kelly and Lauderdale (1999) suggests that mentoring programs can systematically meet career development needs-thus enabling the organization to address successfully, its own need for management succession. Research demonstrates that productivity results improve from $22 \%$ for training alone to $88 \%$ when couching is added to training. Mentoring skills therefore ensures that the mentee is very conversant with the job description, which will in turn enhance his or her performance in order to meet up with the set standards.

Hypothesis One: There is no significant relationship between mentoring and the maintenance of high performance standards

\subsection{Relationship between Management Development and Maintaining High Performance Standards}

Management development is the overall concept that describes the many ways that organizations help employees develop their personal and organizational skills, either as managers in a management job 
or with an eventual job in mind. While, performance standards provides the employee with specific performance expectations for each major duty. They are the observable behaviors and actions which explain how the job is to be done, plus the results that are expected for satisfactory job performance (Amah and Jaja, 2013). Organizations with positive ambitions could make available a framework within which high levels of motivation could be accomplished through provisions of opportunities for learning and development. According to Herzberg, employees are motivated by their own inherent need to accomplish something at a challenging task. The manager's job then is not to motivate employees to get their tasks achieved; rather, the manager should provide opportunities for people to achieve their task so that they will become motivated (Marchington \& Wilkinson, 2005).

Hypothesis Two: There is no significant relationship between mentoring and the maintenance of high performance standards

\section{RESEARCH METHODOLOGY}

The research method adopted for this study is the cross sectional survey design, as well as a quantitative methodology, while data is generated using structured questionnaire copies. It will be almost impossible to deal with the entire fast food companies in Nigeria because of the geographical dispersion of the fast foods and the range population, hence, an accessible portion of the population was selected. Using the cluster technique, the accessible population is the twenty one (21) registered and functional fast food companies in Port Harcourt. The total population for the study is the number of managers and supervisors of the twenty one (21) fast food companies which is seventy seven (77). In determining the sample size, for this study, the Taro Yamen's formula was adopted with a 0.05 error precision (Okpu \& Kpakol, 2015). Based on the calculation the sample size for this study is 65 supervisors and managers, however as a result of the data cleaning process for retrieved questionnaire copies, only 62 copies $(95 \%)$ were considered useful for the study.

Table1. Reliability of instruments

\begin{tabular}{|l|l|l|l|}
\hline Construct & No. of indicators & Cronbach Alpha \\
\hline \multirow{2}{*}{ Succession Planning } & Mentoring & 4 & .916 \\
\cline { 2 - 4 } & Management Development & 4 & .915 \\
\hline \multirow{2}{*}{ MHPS } & 3 & .898 \\
\hline
\end{tabular}

Where MHPS = maintaining high performance standards

Source: Data result, 2015

\section{RESUltS}

This section is concerned with the presentation of the results of the analysis on the data. The demographic section captured data for the distribution of the sample based on certain characteristics such as gender, age, marital status and experience with the organization; the primary level captured data on the distribution of the constructs and their measures using central tendencies and response disparity statistics (primary level of analysis); the results from the primary level were further analyzed based on bivariate-construct association examination as a means to answering previously hypothesized assumptions of bivariate associations (secondary level of analysis).

\section{Demographic data analysis}

Analysis in this section focused primarily on the use of frequency and percentage distributions in the presentation of the data; this is based on the discrete nature of the data; hence a nominal and ordinal scaling.

The result of the demographic analysis reveals a higher number of the participants to be male; results also show that most of the participants are married and hold first degree certifications; probably a prerequisite with regards to recruitment. Furthermore, demographic characteristics indicate most of the workers to be in their thirties; indicating the preferences within the industry as regards age categories and with most having work experiences ranging between $6-10$ years. 
Baba, A. Samuel \& Edwinah, Amah

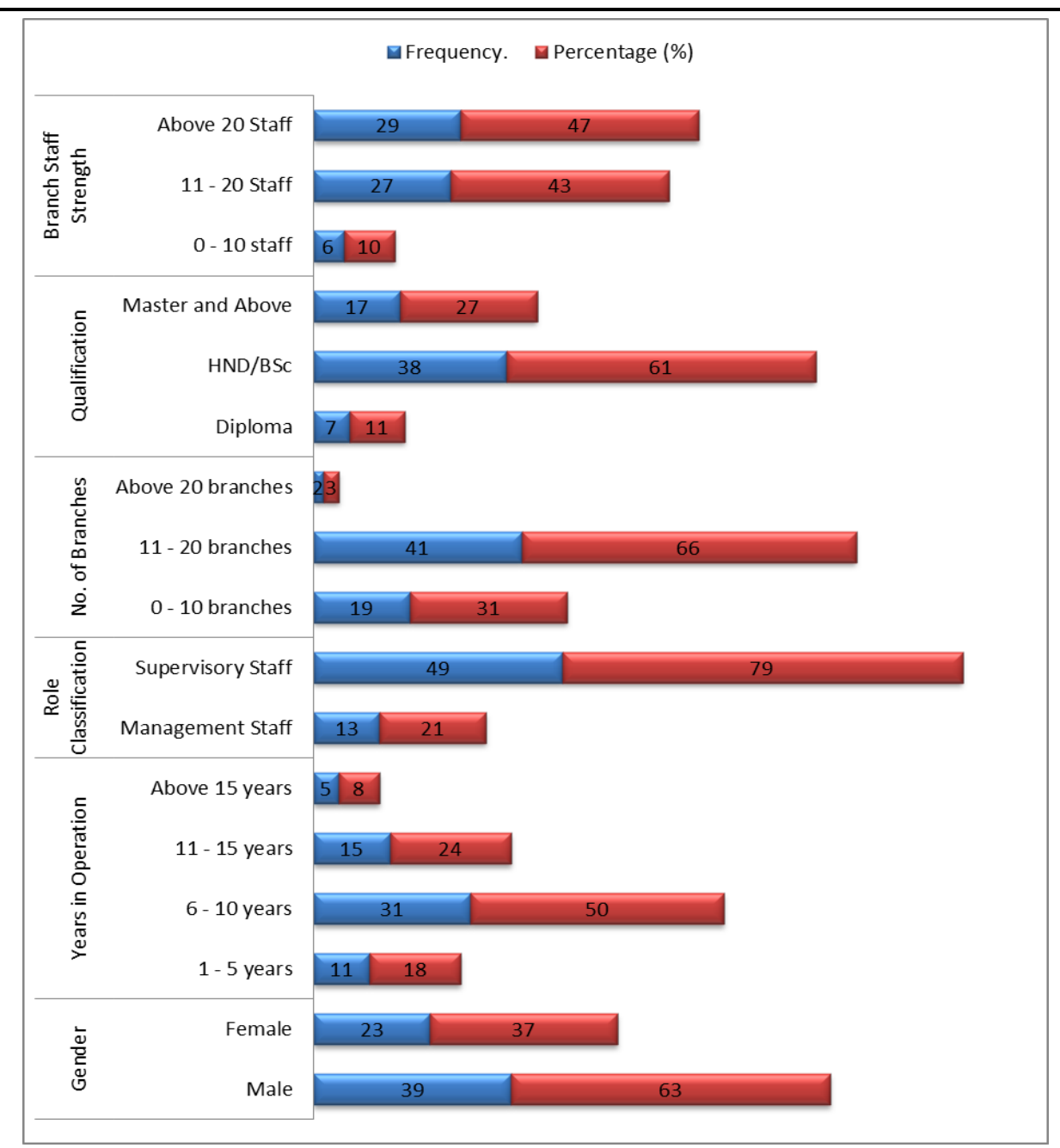

Fig2. Chart for Demographic distribution

Table2. Summary of descriptive on the dimensions of organizational succession planning

\begin{tabular}{|l|l|l|l|l|l|}
\hline & $\mathbf{N}$ & Minimum & Maximum & Mean & Std. Deviation \\
\hline Mentoring & 62 & 1.25 & 5.00 & 4.2177 & .92160 \\
\hline Develop & 62 & 1.25 & 5.00 & 4.1089 & .81560 \\
\hline Valid N (listwise) & 62 & & & & \\
\hline
\end{tabular}

Where develop = management development

Source: Research data, 2015

The data (table 2.) illustrates the summary of the statistics for the dimensions of the predictor variable - organizational succession planning (mentoring, $\mathrm{x}=4.2177$; management development, $\mathrm{x}=4$.1089) with summarized values for central tendency based on the responses to the indicators. Results reveal high affirmative summaries for each dimension

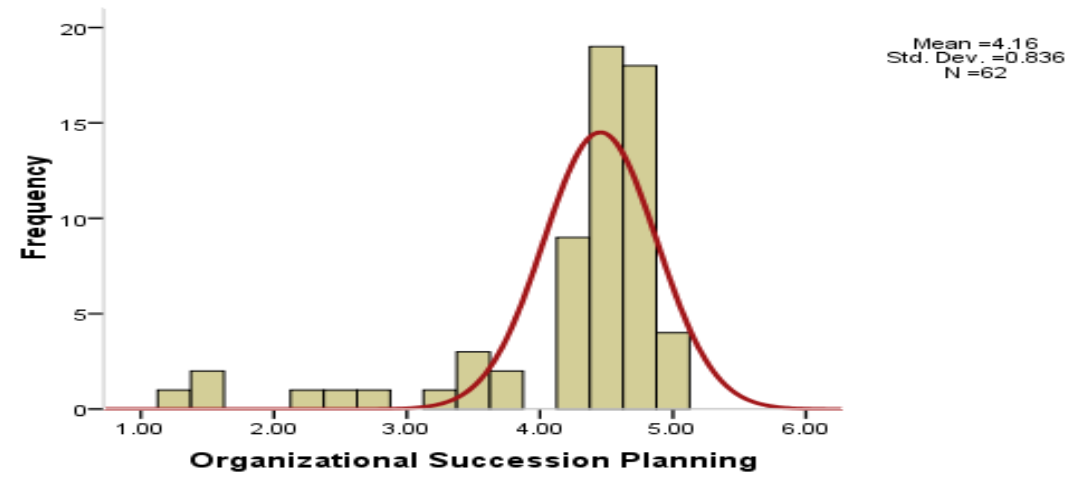

Fig3. Chart for organizational succession planning 

Nigeria

Data (figure 3) illustrates the chart for the predictor variable - organizational succession planning (where $\mathrm{x}=4.1600$ ) indicating high affirmative and agreement to the participants experience and practice of the construct within the organization.

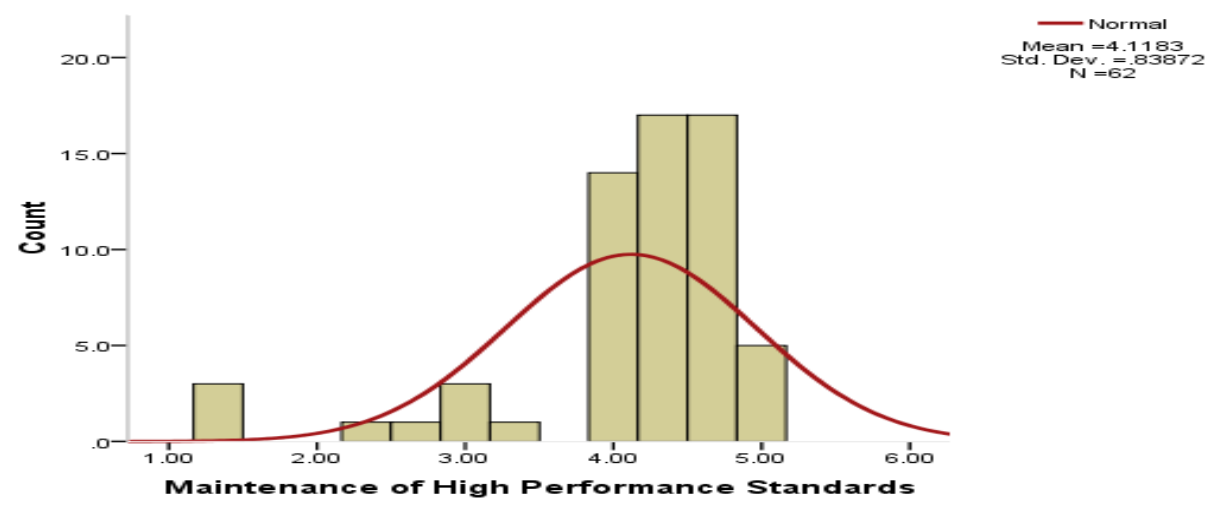

Fig4. Chart for maintenance of high performance standards

Data (figure 4) illustrates the chart for the criterion variable - maintenance of high performance standards (where $\mathrm{x}=4.1183$ ) indicating high affirmative and agreement to the participants experience and observation of the construct within the organization

Table3. Tests for hypotheses

\begin{tabular}{|c|c|c|c|c|c|}
\hline & & & Mentoring & Develop & MHPS \\
\hline \multirow[t]{9}{*}{ Spearman's rho } & \multirow[t]{3}{*}{ Mentoring } & Correlation Coefficient & 1.000 & $.388^{* *}$ & $.504^{* * 4}$ \\
\hline & & Sig. (2-tailed) & & .002 & .000 \\
\hline & & $\mathrm{N}$ & 62 & 62 & 62 \\
\hline & \multirow[t]{3}{*}{ Develop } & Correlation Coefficient & $.388^{* *}$ & 1.000 & $.719^{* * *}$ \\
\hline & & Sig. (2-tailed) & .002 & & .000 \\
\hline & & $\mathrm{N}$ & 62 & 62 & 62 \\
\hline & \multirow[t]{3}{*}{ MHPS } & Correlation Coefficient & $.504^{* *}$ & $.719^{* *}$ & 1.000 \\
\hline & & Sig. (2-tailed) & .000 & .000 & \\
\hline & & $\mathrm{N}$ & 62 & 62 & 62 \\
\hline
\end{tabular}

Where develop = management development $;$ Where $M H P S=$ maintaining high performance standards

Source: Research data, 2015

Hypothesis One: There is no significant relationship between mentoring and maintaining high performance standards - data (table 3 ) reveals that there is a significant relationship between mentoring and the maintenance of high performance standards (where rho $=.504$ and $p<0.05$ ) hence we find that mentoring is strongly associated with the maintenance of high performance standards and based on a decision rule of $\mathrm{p}<0.05$ for null hypotheses rejection; we therefore reject the null hypothesis and restate that there is a significant relationship between mentoring and the maintenance of high performance standards.

Hypothesis Two: There is no significant relationship between management development and maintaining high performance standards - data (table 3) reveals that there is a significant relationship between management development and the maintenance of high performance standards (where rho $=.719$ and $p<0.05$ ) hence we find that management development is strongly associated with the maintenance of high performance standards and based on the decision rule of $p<0.05$ for null rejection; we therefore reject the null hypothesis and restate that there is a significant relationship between management development and the maintenance of high performance standards.

\section{Discussion}

The result of the analysis revealed a highly significant level of association between the dimensions of succession planning and the maintenance of high performance standards hence corroborating the argument of previous studies (Umoh, 2009; Agulanna and Awujo, 2005) which proffer effective succession planning strategies as being fundamental to organizational performance, leadership effectiveness, corporate and thus organizational continuity. Both null hypothetical statements were 
thus rejected and restated as statements of findings based on the observed relations between the constructs. The bivariate results suggest that through effective succession planning, the activities and operations of the organization maintain a measurable form of predictability and stability as a result of the successful transfer of office and leadership based on understanding and planned intent (Gunderson and Hourani, 2003; Palmer and Johnson, 2005).

This is in line with Umoh's (2009) assertion that organizations should endeavour to maintain a homeostatic equilibrium or what can be considered a state of steadiness through consistent succession planning (mentoring and development) systems structured as cultural norms in such a way that allows for the of an error control measure as well performance adjustments based on outcomes and feedback; adjustments in terms of environmental inputs and specialized facilities which checks which affects the organization, enabling it to survive on negative entropy (Mcshane and Von Glinow, 2006; Amah and Jaja, 2013).

\section{CONCLUSIONS AND RECOMMENDATIONS}

In conclusion the study finds that succession planning affects organizational survival and thus enhances outcomes such as adaptability, maintenance of high performance standards and achieving high performance goals. This relationship is further significantly enhanced by the culture of the organization; hence based on the evidence of this empirical endeavour we assert that mentoring as an attribute and dimension of succession planning is imperative for the maintenance of high performance standards; thus facilitating organizational continuity. The study also concludes that management development as a dimension of succession planning is important for attaining the maintenance of high performance standards thus enabling the organization through aspects of leadership stability and predictability to maintain and sustain organizational activities and operations.

Therefore we recommend that concepts like mentoring be encouraged and emphasized within the organization; this would foster leader-subordinate relationship and allow for understanding and effective communication of ideas in such a way that leader actions and intentions are clearly understood and can be followed up by in-coming leaders and policies and goals consistently followed up in spite of leadership change, also management development activities be prioritized as regards performance standards since this would enable the identification and selection of potential leadership successors within the organization and would also facilitate the coordination of succession activities, thus avoiding the negative and unnecessary competition most often associated with succession especially within the organization.

\section{REFERENCE}

Agulanna, C. Edward and Awujo, C. Austine (2005). Human Resource Management - A graphic Approach. Imo State, Career Publishers.

Ahiauzu, A. (1999). The African Industrial Man. Port Harcourt, CIMRAT Publications.

Amah, E. (2010) Hurnan Resource Management. Port Harcourt Amethyst \& Colleagics Publishers.

Amah, E. (2014). Corporate Culture and Organizational Effectiveness. Ibadan, Nigeria. Ibadan University Press.

Amah, E. and Baridam, D. (2012). Adaptability and Organizational Effectiveness: A Study of the Nigerian Banking industry. International Journal of Business Management Tomorrow. 2 (3):122-131.

Amah, E. and Daminabo-Weje, M. (2004). Fundamentals of Management. Port Harcourt, Davidstone Publishers.

Armstrong, M. (2000). Strategic Human Resource Management: A Guide to Action. United Kingdom: Kogan Page Limited.

Armstrong, M. (2006). A handbook of human resource management practice. United Kingdom (10 ${ }^{\text {th }}$ ed), Kogan Page Limited.

Armstrong, M. (2006). A handbook of human resource management practice. London, Kogan Page Limited, (6), 363-387.

Armstrong, M. (2009). Armstrong's handbook of human resource management practice. U.S.A. Library of Congress Cataloguing In Publication Data.

Baridam D. M. (2001). Research methods in administrative sciences, Port Harcourt. 
Succession Planning and the Maintenance of High Performance Standards by Fast-Food Companies in Nigeria

Beckhard, R. and Dyer, W.G (1983). "Managing continuity in the family owned business" Oiganizctonal Dynamic 24 (3):5-7.

Brockhouse, R. H. (2004). "Family business succession: suggestion for future research", Family Business Review 19(2): 165-177.

Burke, D. R. (2005), Succession planning and management. a guide to organizational effectiveness Centre for Creative Leadership. Englewood: Family Enterprise Publishers.

Caudron, S. (1999). The looming leadership ipeline: How to build the leadership - power company. San Francisco: C. A. Jossey-Bass Inc, Publishers.

Charan, R., Drotter, S., and Noel, J. (2001). The leadership powered company. San Francisco, GA: Jossey-Bass (Owned by John Wiky \& Sons, Inc).

Charles, W. L. Hill (2003). International Business: Competing in the global Market Place. Fourth Edition. North America: McGraw Hill Higher Education.

Conor and Carson (1982). Manpower planning and development: the development world. Boston International Human Resources Development Corp.

Cumng, M, W (1993). The theory and practice of personnel management. ( $7^{\text {th }}$ Edition), London: Heinemann.

David, B. (2008). Succession and development, Published in Lean .g executive, an online journal from ASTD.

David, J. David (2011). Dynamic capabilities: a guide for managers. Ivy Business Journal.

David, W. Delng (2004). Lost knowledge: confronting the threat of an aging workforce. USA: Aniazon, Inc.

Davis, P. A. (1983) "Realizing the potential of the family business". Australian: CPA 69(10): 62.

Denison, D. R. (1984). Bringing corporate culture to the bottom line. Organizational Dynamics 13(2):5-22.

Drucher, P. (2008). The five most important questions. San Francisco- Jossey-Bass.

Dunemann, M. \& Barrett, R. (2004). Family business and succession planning: A review of the literature. Research Paper, Berwick: Monash University. Family aid Small business Research Unit.

Essays, U. K. (2013). SMEs role in national economies economic essay. http:/www.ukessay.com

Fillet, A. (1976). Managerial process and organizational behaviour. Scott, Illionis, Fore Sman and Co.

Frankline, J. (1987). New management techniques. London: Gameson Press.

Fulner, E. W (2005). Business strategy and succession planning. Arizona: Duke Corporate Education Publication.

Garman, A.N., Glawe, J. (2004). Succession planning. Consulting Psychology Journal: Practice \& Research, 56(2), 119-128.

Gordon, G. E. and Rosen, M. (1981). "Critical factors in leadership succession", Organizational Behaviour Human Performance 27(2): 227-254.

Gray, W. A. (1986). Formalized mentoring. Canadian Public Administration, 5 (4), 327-339.

Gunderson, I. H., Rolling, C. S. and Peterson, G. D. (2002). Surprise and sustainability: cycles of Renewal in the Everglades Panarchy. USA. Island Press.

Hacket, P. (1979). Succession in management personnel. London: John Murray.

Hazarika, A. (2000). Building the pipeline: leadership succession is a key challenge. Leadership in Action 29(4): 8-12.

Herzberg, F, (2008). One more time: how do you motivate employees (A Review of Herzberg Work by Harvard Business School). Boston Harvard Business Press.

Hirsh. W (2000). Secession planning demystified. A report 372, Institution for Employment studies, October.

Hitt, M. A., Ireland, D. R. \& Hoskisson, R. E. (2005). Strategic management implications. California: Sage Publications, Inc. 
Holling, C. S., Gunderson, L. H. and Ludwig, D. (2002). In quest of a theory of adaptive change. Panarchy. USA: Island press.

House, R. J., (1996). Path goal theory of leadership: lessons, legacy and reformulated theory, Leadership Quarterly 7(3):323-352 <PDF> [Electronic Version].

Ibrahim, A., Soufani, K. \& Lam, J. (2001). A study of succession in a family firm. Family Business Review. 14, 245-258.

McElwain, J. C. (1991). Succession plans designed to change hr magazine. 87-71.

McManus, S, Seville, F., Vargo, J. and Brundsdon, D. (2008). Facilitated process for improving organizational resilience. Natural Hazards Review 9 (2): 81- 90.

McShane, S. L. and VonGlinow, M. A. (2006). Organizational behaviour, emerging realities for the workplace revolution. $4^{\text {th }}$ ed. McGraw Hill Companies Inc. N Y.

Michael Armstrong, (2006). A hand book of human resource management practice. (10 ${ }^{\text {th }} \mathrm{ed}$.) London. Kogan Page Limited.

Milkovich, G. T., \& Newman, J. M. (2008). Compensation. Boston: Irwin McGraw Hill.

Mintzberg, H. (1979) Structure in 5"s: a synthesis of the research in organization design management science.

Mitroff, H. (2005). From my perspective: lessons 9/11. are companies, better prepared today? Technological Forecasting \& Social Change, 72 (3), 375-370.

Mullins, L. J. and Aldrich, P. (1998). 'Integrated model of management and managerial development. Journal of Management", 7 (3): 29-19.

Nickels, G., McHugh, J. M. and Mellugh, S. M. (2011). Understanding business. $9^{\text {th }}$ ed. New York. Irwin McGraw-Hill.

Okpu. T. \& Kpakol A.G (2015) Managing employee trust perceptions for sustained workplace harmony in the Nigerian banking industry. International Journal of Managerial Studies and Research, 3(5): $65-73$

Sherman, A. W., Bonlander, G. W. and Chruden, H. J. (1988). Managing human resources. Cincinnati Chicago, South-Western Publishing Co.

Smith, D. (2006). Beyond contingency planning: towards a model of crisis management, In D. Smith $\&$ D. Elliot (Eds), Key Readings in Crisis Management, Systems and Structures for Prevention and Recovery. New York, Reutledge.

Umoh, G. I. (2009). Management information system with practical case studies. Port Harcourt Blue Print Limited.

Weick, K. E., Sutcliffe, K. M. (2001). Managing the unexpected workshop. Jacks onville, Florida. $1-20$. 